\title{
Högerextrem terrorism och ultramilitans som gruppfenomen? Gruppens inverkan i högerextrema radikaliseringsprocesser
}

\author{
Daniel Köhler
}

SAMMANDRAG: Daniel Köhlers artikel utvecklar en teoretisk modell för att förklara radikalisering genom att se till de interaktionsmekanismer som binder samman radikala sociala rörelser med deras omgivande samhällen och deras övergripande samhällsvisioner eller "målsamhällen" (Zielgesellschaften). Detta i syfte att identifiera och kontextualisera de relevanta grupprelaterade faktorer och mekanismer som är verksamma i sådana processer. Modellen bygger på resultat från den tyska högerextrema miljön men är också tillämpbar på andra, religiösa och politiska, radikala miljöer. Interaktionsteorins kärna, det "radikala kontrastsamhället", utgörs av de radikala sociala rörelsernas ideologi och infrastruktur, deras interna hierarkier och samhällsvisioner. De specifika mekanismerna bakom såväl individuella som grupprelaterade radikaliseringsprocesser förklaras mot bakgrund av kontrastsamhällets enskilda element.

NYCKELORD: högerextrem terrorism; radikalisering; radikal miljö; radikala sociala rörelser; militans; interaktionsmodell; motkultur.

PUBLICERINGSHISTORIK: Översättning av artikeln ”Rechtsextremer Terrorismus und Ultra-Militanz als Gruppenphänomen? Der Einfluss der Gruppe auf rechtsextreme Radikalisierungsprozesse" från Zeitschrift für Internationale Strafrechtsdogmatik, nr $920 \mathrm{I} 4$.

DANIEL KÖHLER är chef för German Institute on Radicalization and De-radicalization Studies (GIRDS).

E-POSTADRESS: contact@girds.org

FÖRSLAG PÅ KÄLLANGIVELSE:

Köhler, Daniel (20I6) "Högerextrem terrorism och ultramilitans som gruppfenomen? Gruppens inverkan i högerextrema radikaliseringsprocesser", i Det vita fältet III. Samtida forskning om högerextremism, specialnummer av Arkiv. Tidskrift för samhällsanalys, $\mathrm{nr}$ 5, s. III-I39.

DOI: http://dx.doi.org/IO.I3068/2000-6217.5.5

\section{(C) original: Zeitschrift für Internationale Strafrechtsdogmatik 20I4}

(C) svensk version: Daniel Köhler/Arkiv förlag \& tidskrift 2016 (publicerad ı8 april 20ı6)

Artikeln distribueras enligt en upphovsrättslicens från Creative Commons:

Erkännande-Ickekommersiell-IngaBearbetningar 3.0 Unported, som medger fri ickekommersiell användning och spridning i oförändrat skick så länge källan anges. 
Arkiv. Tidskrift för samhällsanalys är en sakkunniggranskad vetenskaplig tidskrift för samhällsvetenskap och historia. Samtliga artiklar publiceras fritt tillgängliga på:

$$
\text { www.tidskriftenarkiv.se }
$$

(beständig länk, DoI: http://dx.doi.org/IO.I3068/2000-62I7)

Den här artikeln finns tillgänglig i följande format:

PDF \& HTML: via beständig länk, DOI: http://dx.doi.org/IO.I3068/2000-6217.5.5

EPUB: ingår i e-boksutgåva av numret, ISBN: 978 9I 79242763

TRYCK: ingår i bokutgåva av numret, ISBN: 978 9I 7924277 O

Grafisk utformning och sidnumrering är identisk i pdf och tryck.

Samtliga artiklar i nr 5 (20I6), Det vita fältet III. Samtida forskning om högerextremism, nås via beständig länk, DoI: http://dx.doi.org/IO.13068/2000-6217.5

Redaktion för numret: Mats Deland, Paul Fuehrer, Fredrik Hertzberg och Thomas Hvitfeldt

Arkiv. Tidskrift för samhällsanalys ISSN: 2000-62I7 (för elektronisk resurs) ISSN: 2000-6225 (för tryckta nummer)

ges ut av

Stiftelsen Arkiv för främjande och spridning av samhällsvetenskaplig och historisk forskning

genom

Arkiv förlag \& tidskrift

Box 1559

SE-22I OI Lund

ВESÖK: L Gråbrödersg 3 c, ipg

TEL: 046-I3 3920

ARKIV FÖRLAG: arkiv@arkiv.nu·www.arkiv.nu

TIDSKRIFTEN ARKIV: red@tidskriftenarkiv.se · www.tidskriftenarkiv.se

ANSVARIg UTGIVARE \& CHEFREDAKTÖR: Sven Hort

ADMINistrativ RedAKTÖr: David Lindberg

ReDAKTörer: Paavo Bergman, Lisa Kings, Zhanna Kravchenko 


\title{
Högerextrem terrorism och ultramilitans som gruppfenomen? Gruppens inverkan i högerextrema radikaliseringsprocesser
}

\author{
DANIEL KÖHLER
}

\section{Inledning}

Den sociala relevansen av högerextrem terrorism och ultramilitans fick ökad och hittills oöverträffad uppmärksamhet i det allmänna medvetandet i Tyskland i och med den slumpmässiga upptäckten av Nationalsozialistischer Untergrund $(\mathrm{NSU})^{\mathrm{I}}$ 2OII och den globala uppståndelsen kring norrmannen Anders Behring Breiviks attentat. Trots att enstaka högerterrorister tidigare uppmärksammats under kort tid på grund av enskilda sensationella attacker (till exempel attentatet mot oktoberfesten I980) eller processer (till exempel terroristprocesserna i Bückeburg 1979²), ledde denna uppmärksamhet på lång sikt förvånansvärt nog inte till ett ökat kunskapsintresse när det gäller högerextrem militans och radika-

I. Nationalsocialistiska underjorden, tysk terrorgruppp som mördat minst tio människor sedan slutet av 1990-talet. Red. anm.

2. I denna rättegång åtalades ett antal högerextremister från miljön kring den nynazistiske aktivisten Michael Kühnen och de av honom grundade organisationerna Wehrsportgruppe Werwolf och Aktionsfront Nationaler Sozialisten/Nationale Aktivisten. Red. anm.

Artikeln är ursprungligen publicerad som "Rechtsextremer Terrorismus und UltraMilitanz als Gruppenphänomen? Der Einfluss der Gruppe auf rechtsextreme Radikalisierungsprozesse" i Zeitschrift für Internationale Strafrechtsdogmatik, nr 92014 (http:// www.zis-online.com/dat/artikel/20I4_9_853.pdf), och återges här efter vänligt tillmötesgående från tidskriften. Originalartikelns engelska citat återges här på svenska. 
lisering. Forskningen kring fenomenet högerterrorism och besläktade radikaliseringsprocesser förblev under lång tid sporadisk (Backes 2012, s. 56; Borstel \& Heitmeyer 20I2; Fromm 1998; Hoffman 1986; Jesse 20I2; Köhler 20I4a; Pfahl-Traughber 20I2a och 20I2b; Rabert 1995).

Det finns enstaka studier som har påvisat gruppens betydelse för högerextremt våld, i synnerhet genom analyser av domstolsbeslut, utredningar och intervjuer med inspärrade brottslingar (Kalinowsky 1985; Mentzel 1998; Neubacher 1998; Wahl 200I och 2003; Wendt m.fl. 2002; Willems m.fl. 1993; Willems m.fl. 1994). Däremot har gruppens egentliga inflytande på individuella former av radikalitet, som inte medför straffrättsliga åtgärder, hittills inte uppmärksammats i större utsträckning. Högerextremt våld betraktas visserligen som ett gruppfenomen par excellence, men exakt hur gruppen bidrar till radikaliteten har än så länge endast undersökts i ett fåtal studier som därtill är tämligen ytliga.

Förutom särskilda förklaringsfaktorer, exempelvis gruppspecifik våldsestetik (jfr t.ex. Jaschke 2006; Ueltzhöffer 1993) eller hypermaskulinitet (Zick \& Küpper 2009; Clarke 1979; Hinrichs 2003; Möller 2005; Neumann \& Frindte 2002; Rippl m.fl. 1998), utpekades ofta, och utan vidare fördjupning, betydelsen av särskilda, våldsbejakande subkulturer (som skinnskallar), upplevelser av social segregation och disintegrering eller individuella erfarenheter av våld etc. (Heitmeyer 1992; Hopf \& Schmidt 1993; Möller \& Schuhmacher 2007; Rippl 2002; Rippl \& Seipel 2002; Wahl 2003).

Dessa patologiska förklaringsmönster räcker emellertid inte långt när man inom ramen för den högerextrema miljön försöker förklara variationer i livshistorier (determinismproblemet). Det finns exempelvis många extremt radikala och militanta högerextremister som inte alls stämmer in på profilen "lågutbildade och socialt marginaliserade offer för moderniseringen" (Klönne 1989). Dessutom förbises ofta det faktum att de flesta personer som upplevt motsvarande brister i uppväxtförhållanden och socialisation inte alls genomgår en politisk eller religiös radikalisering.

Vi kan konstatera att den konkreta interaktionen mellan grupp och individ i samband med radikaliseringsprocesser i allmänhet, och denna interaktions växelverkan med den radikala miljöns övergripande samhällsvision (målsamhället) i synnerhet, fram till i dag inte undersökts mer 
än sporadiskt. Dessutom används själva termen "radikalisering” ganska sällan och med stor försiktighet i tysk forskning om högerextremism.

Denna artikel ägnas åt gruppspecifika påverkansfaktorer till högerextrema radikaliseringsprocesser med avseende på militant och terroristiskt beteende, men undersökningen är inte begränsad till aspekter av radikalisering som våld eller illegalitet. Syftet är snarare att belysa radikalitetens och radikaliseringens dynamik med hjälp av en teoretisk modell av interaktionsmekanismerna mellan radikala miljöer (här: radikala sociala rörelser) och deras samhälleliga kontext och samhällsvision. Avsikten är att kunna analysera och förstå enskilda radikaliseringsförlopp, militant gruppbeteende samt motsvarande strategier inom extremhögern utifrån den högerextrema miljöns specifika kontext. Den interaktionsmekanism som presenteras här (det radikala alternativsamhället) baseras visserligen på praktiska insikter om strukturer och radikaliseringsprocesser i den tyska högerextrema miljön, men den kan även tillämpas på andra former av radikalitet och politiska samt religiösa extrema miljöer. Det innebär dock inte att dessa miljöer liknar varandra när det gäller ideologiskt innehåll eller grupperingar. Modellen som presenteras i denna artikel fokuserar på interna och externa drivkrafter eller, för att vara mer exakt, på interaktionsmekanismer mellan dessa radikala grupper och deras omgivande samhällen, och inte på särskilda grupper i sig. Detta möjliggör jämförelser mellan olika typer av radikala rörelser i syfte att fastställa likheter och skillnader.

Föreställningen om en kontra- eller motkultur som baseras på en konflikt med ett dominant samhälle har sitt viktigaste ursprung i Milton Yingers berömda artikel om kontrakulturer och subkulturer (Yinger 1960) samt Theodore Roszaks (1969) bok The Making of a Counter Culture. Även om Yinger i sin huvudsakligen teoretiska bok i ämnet (Yinger 1982) ändrade begreppet från "kontrakultur" till "motkultur" (counterculture) bibehöll han sin huvudsakliga definition av fenomenet. Han betecknade dessa kulturer som synliga "varhelst en grupps normativa system som en primär komponent innehåller ett tema som står i konflikt med det totala samhällets värderingar, där personlighetsvariabler direkt involveras i utvecklingen och upprätthållandet av gruppens värderingar, och varhelst dess normer bara kan förstås i förhållande till gruppens 
relationer med den omgivande dominerande kulturen” (Yinger 1960, s. 629).

Förutom Yingers och Roszaks begrepp "motkultur" utvecklades ännu fler teorier för att beskriva grupper som uppfattas som mer extrema och radikala än de flesta andra subkulturerna, till exempel om oppositionskultur (oppositional culture) (jfr Adams \& Roscigno 2005; Gamson 1995) och motrörelse (counter movement) (Meyer \& Staggenborg 1996). Dessa begrepp, i synnerhet teorin om en motkultur, utgår från gruppens eller rörelsens behov av separation från, och opposition mot, det omgivande samhället. Denna separation och opposition är av central betydelse för den teoretiska modell av ett radikalt alternativsamhälle som presenteras nedan. Radikala sociala rörelser har karaktären av motkulturer i den meningen att de av princip ställer sig i opposition till en dominerande kultur (eller ideologi), men de måste undersökas utifrån ett mycket bredare och mer komplext synsätt (analogt med sociala rörelser) om vi ska förstå såväl rörelsens praktiker som individuella radikaliseringsprocesser inom rörelsen.

\section{Vad är "radikala sociala rörelser"?}

Det finns ingen brist på definitioner av, och teorier om, sociala rörelser per se eller frågan huruvida man kan tala om sociala rörelser när det gäller vissa extrema eller radikala grupper (till exempel högerextrema, jihadister, radikala miljöaktivister) (Dalgaard-Nielsen 2008; della Porta 1995 och 2013; Ezekiel 2002; Koopmans \& Rucht 1996; McVeigh m.fl. 2004; Pfahl-Traughber 2003; Sageman 2008; Virchow 2004; Zeskind 2009).

I den här artikeln används Dianis definition av sociala rörelser som grundval. Han definierar fenomenet som "nätverk av informella interaktioner mellan en mångfald av individer, grupper och/eller organisationer, som är engagerade i politiska eller kulturella konflikter, baserat på gemensamma kollektiva identiteter" (Diani 1992, s. I).

Även hos Diani har således konflikten i sig en central betydelse för att förklara dynamiken i sociala rörelser. Trots att stora delar av forskningen om sociala rörelser har koncentrerat sig på fredliga rörelser, som frivilligt integrerar sig i det omgivande samhället, finns det ändå ett antal omfat- 
tande studier av våldsamma, hemliga och radikala grupper. Mekanismerna för gruppens interaktion med sin omgivning är emellertid fortfarande till stor del outforskade. I en grov indelning går det att urskilja fem olika skolor i den internationella forskningen om sociala rörelser: collective behaviour (Turner \& Killian 1987), resource mobilization (Garner \& Zald 1985; McCarthy \& Zald 1973 och 1977), political process (Tilly 1978 och 1984), new social movements (Melucci 1992; Touraine 1977, 198I och 1985) samt framing theory (Benford 1993; Benford \& Hunt 1992; Benford \& Snow 2000; Chong \& Druckman 2007; Snow \& Benford 1992; Snow m.fl. I986).

I den här artikeln kommer endast inramningsteorin (framing theory) att beaktas närmare eftersom den uppvisar störst kongruens med några element av teorin om kontrastsamhällen. Inramningsteorin (för en översikt se Benford \& Snow 2000) betraktar inte sociala rörelser "i första hand som bärare av bevarade idéer och betydelser som växer automatiskt ut ur strukturella arrangemang, oförutsedda händelser, eller existerande ideologier" (Borah 20II, s. 246). Här är aktörerna aktiva deltagare i en process som implicerar "agentskap och motsättning på verklighetskonstruktionens nivå” (Benford \& Snow 2000, s. 6I4). Enligt Borah (20II) behandlar inramningsteorin något förenklat två huvudsakliga aspekter: kommunikation och politiska problem. Medan forskningen på kommunikationsområdet analyserar hur ord, bilder, meningar etc. används för att konstruera berättelser som handlingsramar, koncentreras analysen av politiska problem på "hur ett handlingssätt där en central idé ger en händelse mening kan karakteriseras" (Borah 20II, s. 248). Sammanfattningsvis beskriver begreppet "kollektiva handlingsramar" (collective action frames) inom inramningsteorin "handlingsorienterade uppsättningar av övertygelser och betydelser som inspirerar och legitimerar en social rörelseorganisations verksamhet och kampanjer" (Benford \& Snow 2000, s. 6I4). Dessa ramar uppfyller enligt Benford och Snow vissa kärnuppgifter. De diagnostiserar ett särskilt problem, ger en prognostiserande framställning av hur problemet kan åtgärdas och motiverar därigenom till en specifik handling (Benford \& Snow 2000, s. 6I4).

Såsom redan nämnts fokuserar en stor del av forskningen om sociala rörelser på utvecklingen av fredliga rörelser som frivilligt integreras med 
sin omgivning. Några kända undantag är Bittner (1963) och Fitzgerald och Rodgers (2000), som tar upp radikala rörelser. Bittner ser radikalism som en "rent social händelse" (Bittner 1963, s. 928) i vilken organisationer eller rörelser avgränsar sig "från den normala, vanliga, traditionellt sanktionerade världsbild som kan återfinnas i varje samhälle och att detta inte är en gradskillnad utan ett uppställande av motsatser" (Bittner 1963, s. 928) och "söker en förenad och inbördes konsekvent tolkning av världens mening" (Bittner 1963, s. 932). Han identifierar följande sju egenskaper hos dessa radikala organisationer eller rörelser (Bittner 1963, s. 936 ff.): I) en karisma som är inneboende i rörelsens centrala läror, 2) en ideologi som baseras på information som ligger utanför vardagslivet, 3) en intensiv upptagenhet med trons eller ideologins renhet, 4) medlemmens absoluta underkastelse under ideologin, 5) en föreställning om lidande som en integrerad del av rörelsens utveckling, 6) en upplösning av relationer utanför gruppen och 7) en omtolkning av extern kritik av rörelsen för egen vinning. På så sätt etablerar Bittner en stark koppling mellan doktrin (eller tro, ideologi) och en strikt, nästan fientlig attityd gentemot den dominerande världsbilden. Den fortsatta diskussionen i denna artikel kommer att visa att denna koppling fortfarande i hög grad underskattas.

En annan inriktning inom forskningen om sociala rörelser har delvis försökt att hantera denna kritik: contentious politics (McAdam m.fl. 2003) analyserar alla typer av "kollektiva politiska strider" där regeringar och informellt konstituerade politiska aktörer deltar med okonventionella medel (som revolutioner, etniska eller religiösa konflikter). Analysen bygger på en uppfattning av konflikten som renodlat relationell och tar upp såväl enskilda episoder av interaktioner mellan flera parter som sociala konstruktionsprocesser. Även om inriktningen försöker att identifiera speciella orsaksmekanismer bakom dessa interaktioner saknas en omfattande teori som kan förklara själva konflikten. Andra viktiga undersökningar inom forskningen om sociala rörelser som behandlar våldsamma och/eller radikala rörelser har genomförts av della Porta (1995 och 2013) och Wiktorowicz (2004a, 2004b och 2006). Ändå tilldrog sig detta forskningsområde förvånansvärt nog endast sporadiskt intresse från samhällsvetenskaperna, med "några korta toppar i perioder 
av mycket uppmärksammade terroristattacker, men liten ackumulation av resultat" (della Porta 2008, s. 22I).

Sammanfattningsvis kan konstateras att forskningen om sociala rörelser än så länge saknar en adekvat teoretisk modell för radikala sociala rörelser som kan användas för att analysera interaktionsmekanismerna med det omgivande samhället. Ändå kan delar av denna korta översikt av forskningen om sociala rörelser lyftas fram som användbara: den centrala roll som konflikten med den "normala" eller "dominerande" världsbilden spelar, ideologins, trons eller doktrinens framstående funktion samt, dock inte tvingande, en strävan att erkänna den rådande "maktstrukturen”. Inom ramen för denna artikel används en arbetsdefinition av "radikala sociala rörelser": nätverk av informella interaktioner mellan ett flertal personer, grupper och organisationer som fungerar som en motkultur vars primära syften är att få inflytande (positivt eller negativt) samt att åstadkomma en grundläggande förändring eller förstörelse av ett framtida samhälle på basis av en religiös eller politisk ideologi med alla tänkbara medel (legala och illegala), inklusive en strategisk eller taktisk användning av våld, för att manifestera en ideologiskt rensad eller korrigerad version av detta samhälle.

\section{Samhällsvisoner och målsamhällen}

I en radikal rörelses vision av samhället kan målsamhället vanligtvis, och i enlighet med rörelsens ideologi, definieras positivt (ett samhälle som bör inkorporeras, ändras, kontrolleras eller övertygas) eller negativt (ett samhälle som bör bekämpas och omintetgöras). Detta målsamhälle bör inte förväxlas med rörelsens omgivande samhälle. Naturligtvis kan dessa överlappa varandra delvis eller helt, men de är i grunden annorlunda till sin natur. En tysk nynazistisk grupp ser exempelvis stora delar av Förbundsrepubliken Tyskland som ett politiskt eller socialt "slagfält" som ska betvingas ideologiskt. Bland annat omfattar gruppens ideologi element såsom återupprättandet av Tredje riket på grundval av nationalsocialismen. Givetvis definierar Tysklands utsträckning före andra världskriget kärnan av det geografiska område som ska kontrolleras. Den tyska befolkningen uppfattas till stora delar också som en positiv målgrupp, 
det vill säga som en grupp som antingen ska övertygas med hjälp av gruppens ideologi eller attraheras av gruppens radikala kamp. Inte ens polis eller militär betraktas per automatik på ett negativt sätt såsom fiender, diskussionen om dem har i stället vållat en del kontroverser inom den högerextrema tyska rörelsen. Å ena sidan uppfattas polisen och militären som del av den demokratiska regeringen och därför som fiender i rörelsens kamp. $\AA$ andra sidan är de en del av det tyska samhälle som rörelsen vill kontrollera och få inflytande över.

Det faktum att vissa tyska nynazister tjänstgör, eller har tjänstgjort, som officerare i försvarsmakten eller som poliser, visar att dessa yrken eller sociala positioner har en viss dragningskraft inom den högerextrema miljön. Ett annat mål för rörelsen, eller delar av rörelsen, skulle kunna vara övertagandet av det tyska samhället med hjälp av politiska val (till exempel av NPD³). På så sätt uppfattar den högerextrema rörelsen stora delar av det tyska samhället (med undantag för utlänningar, demokrater, vänsteraktivister, homosexuella och så vidare) i sig inte som rörelsens fiender utan som helt enkelt vilseledda eller okunniga, vilket i sin tur väcker krav på "upplysning", "uppvaknande" eller "omvandling”. I detta fall är det målsamhälle som omfattas av de positiva och negativa samhällsvisionerna i stort sett identiskt med rörelsens omgivande samhälle, det vill säga Förbundsrepubliken Tyskland. Inte minst på grund av det starka ideologiska sambandet mellan rörelsen och den tyska historien, samt "blod och jord"-kulturen inom den högerextrema ideologin, skapas denna blandning av positiva och negativa visioner av samhället. Negativa målsamhällen med entydigt fientliga kännetecken är ur den högerextrema rörelsens perspektiv ideologiskt definierade fiender som vänsteraktivister, utlänningar och judar. För att identifiera de målsamhällen som omfattas av en radikal social rörelses negativa eller positiva samhällsvisioner krävs ingående kunskaper om rörelsens ideologiska men även politiska, sociala och ekonomiska hemvist i det omgivande samhället. En viktig poäng i detta sammanhang är att vissa radikala sociala rörelser

3. Nationaldemokratische Partei Deutschlands (Tysklands nationaldemokratiska parti) är ett ultranationalistiskt politiskt parti i Tyskland som grundades 1964. Partiet ger uttryck för starkt rasistiska värderingar och betraktas inom statsvetenskaplig forskning allmänt som ett klassiskt nynazistiskt parti. Red. anm. 
kan ha fastnat i spänningen mellan positiva och negativa samhällsvisioner samtidigt som rörelsen utifrån sin ideologi inte, eller endast delvis, kan upplösa denna spänning. Detta innebär att en sådan rörelse ibland definierar delar av det målsamhälle som eftersträvas i rörelsens positiva samhällsvision som rörelsens fiender, samtidigt som dessa delar i syfte att uppnå samhällsvisionen och etablera rörelsens långfristiga ideologiska mål ändå måste påverkas på ett positivt sätt. Dessutom kräver behovet av att rekrytera nya medlemmar för att upprätthålla gruppen, samt ideologins inneboende behov av politisk relevans, med nödvändighet ett utbyte med det samhälle som omfattas av samhällsvisionen för att rörelsen inte ska vara helt isolerad (på så sätt skiljer sig radikala sociala rörelser från exempelvis sekter, som ibland faktiskt kan eftersträva en total isolering från det omgivande samhället). Ett sådant utbyte importerar per automatik nya influenser (till exempel estetiska, ideologiska) till rörelsen och medför samtidigt en risk för en uppmjukning av rörelsens ideologiska kärna. Exakt hur detta utbyte fungerar synliggörs i avsnitten om ideologi och infrastruktur nedan.

\section{Intern skiktning och hierarkier}

Radikala sociala rörelser har med nödvändighet någon form av intern skiktning för att utjämna skillnader mellan dels de nya medlemmarnas sociala och biografiska bakgrunder och dels deras skiftande personliga kvalifikationer. En intern hierarki är dessutom viktig med tanke på de beslutsprocesser som krävs för att fastställa hur rörelsens mål bäst ska uppnås. Många studier har visat att radikala grupper omfattar olika typer av medlemmar med varierande socioekonomisk och biografisk bakgrund (även om endast ett fåtal av dessa studier har utförts inom ramen för forskningen om sociala rörelser). Willems (1993) identifierar exempelvis i sin studie av högerextrema brottslingar fyra typer: I) den politiskt motiverade gärningspersonen, 2) den främlingsfientliga gärningspersonen 3) den kriminella ungdomen och 4) ligisten. Bjørgo (20II) urskiljer tre typer: ideologistyrda aktivister (ideological activists), lösdrivare och anhängare (drifters and followers) samt socialt frustrerade ungdomar (socially frustrated youths). 
Dessa studier framhåller å ena sidan många olika vägar in i den högerextrema miljön, men de implicerar å andra sidan även olika rolluppsättningar och funktioner inom en given rörelse. Integrationen av nyrekryterade medlemmar ur det målsamhälle som omfattas av rörelsens positiva samhällsvision (och om möjligt även ur det målsamhälle som ses som negativt) innebär att rörelsen måste ta hänsyn till rekryternas färdigheter när de inlemmas i gruppens hierarkiska struktur, som vanligtvis inbegriper en sorts elit, medelklass samt underklass. Naturligtvis finns en gruppintern dynamik som innebär att det förekommer vertikala förflyttningar i hierarkin såväl uppåt som neråt. Dessa gruppinterna förflyttningar regleras i regel i strikt överensstämmelse med såväl ideologin (som avgör vilka egenskaper som krävs för att flyttas uppåt i hierarkin) som framtidsvisionen om det ideala samhället (till exempel arbetare eller "ariska" förkämpar som idoler) (Köhler 20I4b, s. 329).

Förutom de uppenbara fördelarna med ett mer effektivt beslutsfattande är det också möjligt att radikala sociala rörelser internt försöker efterlikna det positiva målsamhället (när det gäller social skiktning). På så sätt skulle dessa rörelser kunna sträva efter att erhålla mer trovärdighet och legitimitet som sociala rörelser. Extrema högergrupper, som Hammerskin Nation, ${ }^{4}$ har framför allt försökt att presentera sig som organisationer för "arbetarklassen", medan andra mer elitistiska grupper, som Ku Klux Klan, framställer sig som protestantiska medelklassföreningar. En effekt av den interna skiktningen är dessutom att de olika delarna av en radikal social rörelse i varierande grad uppmärksammas av rörelsens omgivande samhälle (både det positiva och det negativa målsamhället). Medlemmar från rörelsens lägre skikt i den interna hierarkin (till exempel skinnskallar) kan exempelvis uppfattas som i hög grad radikaliserade (vilket i detta sammanhang för det mesta betyder våldsamma och avvikande), trots att extremhögerns högt uppsatta företrädare representerar ett större hot mot samhället som helhet. Detta toppskikt skulle mycket väl kunna uppfattas

4. Hammerskin Nation är en global vitmaktrörelse som startades i Dallas I988. Rörelsen sysslar främst med produktion och spridning av vitmaktmusik. Enligt rörelsens egen hemsida fanns det 2014 förutom sex lokalavdelningar i USA även lokalavdelningar i Australien, Frankrike, Kanada, Luxemburg, Italien, Nya Zeeland, Portugal, Schweiz, Spanien, Sverige, Tyskland och Ungern. Red. anm. 
som konservativa eller till och med extrema, men på grund av sin sociala integration (såsom advokater, läkare, politiker med mera) anses de ändå vara ofarliga. Denna sociala integration, som i viss mening innebär social status och erkännande, är vanligtvis oförenlig med den allmänna föreställningen att radikala rörelser kännetecknas av socialt patologiska drag. En mycket viktig aspekt i detta avseende är en strategisk användning av, och rationell reflektion kring, användningen av våld. Spontant våld som inte passar in i den bredare rörelsens strategiska koncept och mål (till exempel spontana våldshandlingar från skinnskallar), nedvärderas delvis som något som ligger utanför själva rörelsens kärna (Köhler 20I4b, s. 340).

Detta fenomen pekar mot ett nyanserat radikaliseringsbegrepp som anknyter till graden av individuell reflektion kring individuellt beteende i relation till rörelsens övergripande ideologiska mål och värderingar. Detta bör inte förväxlas med intellektuell förmåga eller kunskaper om rörelseideologins teoretiska aspekter. Av betydelse i detta sammanhang är graden av internalisering av grundläggande politiska begrepp (som "våld”, ”ära", "lojalitet", "rättvisa" och "orättvisa") som utgör rörelsens ideologiska kärna, samt strävan att agera i enlighet med dessa värderingar och begrepp. Som utomstående betraktare bör man inte dra slutsatsen att det föreligger en brist på ideologisk relevans eller konsekvens om enstaka rörelsemedlemmar agerar i opposition till några av ideologins specifika värderingar (till exempel nynazister som både konsumerar och säljer narkotika). Medlemmarna kan mycket väl skilja sig åt i sin individuella rangordning och värdering av specifika aspekter av rörelsens ideologiska kärna. Dessutom är det som regel lätt att hitta särskilda pragmatiska lösningar, undantag och förklaringsmönster (till exempel narrativet att rörelsen befinner sig i krigstillstånd vilket nödvändiggör exceptionella åtgärder).

Utöver detta kan våldet och andra former av avvikande beteende som kan kopplas till ett "onormalt" utseende (till exempel skinnskalleklädseln) av det omgivande samhället uppfattas som huvudindikatorn för en radikaliseringsprocess. Medlemmar i rörelsens toppskikt kan strategiskt undvika dessa beteenden och utseendemarkörer för att uppfattas som mindre radikala av sin sociala kontext. Tvärtemot denna uppfattning är det emellertid så att just dessa ranghöga medlemmar av radikala sociala rörelser på grund av sin ideologiska och strukturella betydelse (till exem- 
pel sin ledande funktion, sitt förnyelsearbete med rörelsens taktiker och strategier, sin rekrytering och radikalisering av nya medlemmar samt sin konkreta anstiftan till brott) på lång sikt måste ses som ett större hot mot samhället.

\section{Infrastruktur}

Infrastrukturen, inklusive rörelsens alla synliga delar, är en av de två huvudpelare som knyter samman den radikala sociala rörelsen med dess positiva och negativa målsamhälle. Infrastrukturen kan delas in i följande fyra, delvis överlappande, huvudkategorier.

Händelser är en väsentlig del av rörelsens integration och nätverksbyggande, vilket är en förutsättning för skapandet av en kollektiv identitet. Dessa händelser omfattar en mycket bred kategori av aktiviteter såsom konserter, gudstjänster, möten och manifestationer, studiecirklar, festivaler och helgdagar, men även våldsamma olagliga aktiviteter inklusive terroristhandlingar, attacker mot fiender, protestdemonstrationer med mera. Ett viktigt exempel är betydelsen av musik och konserter för den högerextrema miljön, kanske främst för skinnskallesubkulturen, där musiken får bära upp rörelsens ideologi och främja nyrekrytering och integration av nya medlemmar samt bildandet av nätverk, något som i många studier har visat sig vara grundläggande för högerextrema miljöer (Adams \& Roscigno 2005; Brown 2004; Cotter 1999; Futrell m.fl. 2006; Macklin 2013; Shaffer 2013).

Den ekonomiska infrastrukturen är nära besläktad med händelsedimensionen. Fokus ligger här emellertid på ekonomiska nätverk av radikala sociala rörelser och deras försök att finansiera sin verksamhet i syfte att vara oberoende av andra institutioner (till exempel bidrag från samhällsinstitutioner eller företag som inte är del av rörelsen). Som exempel kan nämnas försäljningen av musik, kläder, föremål med anknytning till rörelsen (souvenirer, flaggor, klistermärken), litteratur, predikningar och föreläsningar samt inkomster från konserter, seminarier och konferenser.

Organisationsdesign (corporate design) omfattar alla visuella element och den estetik som förknippas med gruppen eller rörelsen, som logotyper, webbsidor, vissa ritualer (sånger, böner, marscher och demonstratio- 
ner), koder och symboler. Denna design kan vara mycket genomstrukturerad och statisk eller bara motsvara en viss stil (till exempel ett visst klädmärke). Organisationsdesign är icke desto mindre avgörande för en radikal social rörelse eftersom dess markörer behövs för att bilda en kollektiv identitet och avgränsa sig från det negativa målsamhället och samtidigt associera rörelsen med det positiva målsamhället (till exempel genom upprop eller genom att bära symboler, koder, färger och teman, traditioner samt andra kulturella element som har positiva konnotationer i det positiva målsamhället).

Infrastrukturens individuella nivå omfattar krav på ett specifikt utseende (frisyr, skägg, tatueringar, smycken, kläder) som rörelsens medlemmar förväntas följa. Återigen kan en tvåvägsprocess observeras i detta sammanhang: å ena sidan rörelsen eller gruppen som klassificerar ett specifikt individuellt uppträdande som önskvärt eller ideologiskt korrekt, å andra sidan medlemmarna som på grund av sin önskan att uppfattas som fullvärdiga medlemmar av rörelsen aktivt anpassar sig till gruppens stil (Hundeide 2003).

Sammanfattningsvis förenar infrastrukturen den radikala sociala rörelsen med positiva och negativa målsamhällen i det verkliga livet och utgör förutsättningen för rörelsens synlighet, genomslagskraft och ett rörelsespecifikt socialt liv (så att säga rörelsens hårdvara).

\section{Ideologins roll}

Ideologin är den andra pelaren genom vilken radikala sociala rörelser förenas med målsamhället, och avgörandet av dess betydelse har en lång tradition inom forskningen om sociala rörelser med flera faser av "tilltagande och avtagande" (Snow 2004), vilket inte behöver diskuteras i detalj på detta ställe.

Som regel uppfattas "ideologi" i forskningen om sociala rörelser som en "övergripande term för en relativt stabil och koherent uppsättning av värderingar, uppfattningar och målsättningar eller en bredare, omfattande social enhet, och antas utgöra skäl för att försvara eller utmana olika sociala arrangemang och villkor" (Snow 2004, s. 396). Denna ideologiförståelse har lett till en utbredd kritik av begreppets praktiska användbarhet 
(utan att helt förneka att ideologin spelar en roll för utvecklingsprocessen av kollektiva handlingsramar). Snow (2004, s. 397) identifierade i detta sammanhang fyra avgörande fel i användningen av ideologibegreppet. Med utgångspunkt i avsaknaden av en heltäckande förklaring av exakt hur ideologin är inbäddad i sociala rörelser är utgångspunkten alltför ofta att ideologier uppvisar en större koherens, uppfattas med en större enighet bland rörelsens sympatisörer samt besitter en högre grad av kausalitet mellan tron på ideologin och beteende, än vad som faktiskt är fallet (Snow 2004). Som ett resultat av detta har det analytiska värdet av ideologibegreppet länge varit mycket omstritt inom forskningen om sociala rörelser. I stället används i flera studier begreppet "kollektiva handlingsramar" (collective action frames) som beskriver hur "sociala rörelseorganisationer och deras agenter [...] tillskriver mening till och tolkar relevanta händelser och villkor på sätt som avser att mobilisera potentiella anhängare och deltagare för att samla stöd från åskådare, och avmobilisera antagonisterna” (Snow \& Benford I988, s. 197). Många forskare är överens om att dessa kollektiva handlingsramar är inbäddade i en "grupps övergripande kultur" och att de avgränsas av "aspekter av den bredare kulturen och politiska kontexten" (Snow 2004, s. 385). Vissa går ännu längre och påstår att överensstämmelsen med gruppens ideologi är central för en kollektiv handlingsrams verkanskraft (Gamson 1988, s. 220) eller att frågor om en kollektiv handlingsrams ursprung borde leda fram till ideologins betydelse (Oliver \& Johnston 2000; Steinberg 1998). Men trots dessa ansatser har kritiken mot ideologibegreppet inneburit att det mestadels undviks som analytiskt verktyg, och i stället ligger fokus på det mer användbara begreppet "kollektiva handlingsramar".

Användningen av ett tydligt definierat ideologibegrepp, eller andra närbesläktade teoretiska begrepp, är till skillnad från i forskningen om sociala rörelser sällsynt i forskningen om högerextremism. Även om det i den internationella forskningen har funnits enstaka försök att analysera högerextrem ideologi (Mudde 200o), har tyska studier, förutsatt att de över huvud taget tar upp ideologibegreppet, främst påpekat att högerextrema gärningspersoner i låg grad utmärks av en långt gången "ideologisering" (Frindte m.fl. 200I; Frindte \& Neumann 2002; Frindte m.fl. 2003; Fuchs 2003; Neumann \& Frindte 2002). I detta samman- 
hang uppfattas ideologi för det mesta som dels en ansamling av konkreta attitydmönster eller hållningar (till exempel antisemitism, förhärligande av nazismen, förnekelse av förintelsen) och dels en intellektuell insats när det gäller att skaffa sig en viss expertis genom fackkunskaper hämtade från nazistisk litteratur och teoribildning. En sådan definition av ideologi är emellertid alltför ytlig för att kunna användas i analysen av verkningsmekanismerna i såväl grupprelaterade som individuella radikaliseringsprocesser.

Även om det är allmänt accepterat att alla sociala rörelser baseras på någon form av ideologi, kultur eller trossystem är ett grundläggande argument i denna artikel att radikala sociala rörelser i ännu högre grad kännetecknas av en viss typ av ideologi (som i huvudsak förnekar existensrätten för de ideologier som förknippas med rörelsens negativa samhällsvision, det vill säga det negativa målsamhället). Denna ideologi påverkar inramningsprocessen (eller meningsproduktionsprocessen) och den därmed förknippade dynamiken, såsom mobiliseringen av resurser och politiska möjlighetsstrukturer, i långt större utsträckning än vad som i regel är vanligt för "icke-radikala" sociala rörelser.

För att förstå denna dynamik och ideologins roll i den behövs ett betydligt mer nyanserat och komplext ideologibegrepp. I Michael Freedens (1994) banbrytande arbete om ideologins morfologi beskrivs ideologi som "en organiserande referensram för handlingsorienterat politiskt tänkande" och "tankebyggnader som har funktionen att organisera deras uppfattningar om deras politiska miljöer, att påvisa för dem vissa typer av politiskt beteende, och att tillhandahålla handlingsplaner till stöd för offentliga politiska institutioner" (Freeden I994, s. I40).

Även om denna uppfattning av ideologi verkar vara nästan identisk med definitionen av ramar och inramningsprocesser, som på samma sätt används för att bedöma problem, göra prognoser om framtiden och motivera handlingar (Benford \& Hunt 1992; Snow \& Benford 1988), utvidgar Freeden ideologibegreppet med sin syn på ideologier som "särskilda kluster av mönster och konfigurationer av politiska begrepp. En ideologi är därmed inget annat än det makroskopiska strukturella arrangemang som ger mening åt en uppsättning ömsesidigt definierande politiska begrepp" (Freeden I994, s. I4I). 
Dessa politiska begrepp (till exempel "rättvisa", "frihet", "makt", "rättigheter", "jämlikhet", "val") kan anses gälla som de centrala delarna av varje given ideologi. De är dock organiserade och arrangerade på ett mycket karakteristiskt sätt för olika ideologier och bildar därigenom en sorts ideologiskt fingeravtryck som inte bara är en ansamling av politiska begrepp utan även omfattar beståndsdelar hämtade ur ideologins kulturella och logiska närmiljö såväl som periferi.

Naturligtvis är dessa politiska begrepp inte statiska utan tvärtom mycket flexibla och därmed öppna för en mångfald av språkliga och kulturella betydelser (Freeden 1994, s. 154). Med tanke på att ideologier enligt Freeden alltid är förankrade i en konkret social kontext (socially situated, vilket innebär att de också är relaterade till rörelsens specifika positiva och negativa målsamhällen) samt är inriktade på kollektiva identiteter (vad Freeden 1994, s. I55, kallar partisan value-arbitrated) består ideologins huvudsakliga funktion i att befästa relationen mellan ord och deras betydelser för att i den mån det är möjligt ge varje politiskt begrepp en enda betydelse (Freeden 1994, s. 156). Sålunda strävar varje ideologi efter att minska det tolkningsutrymme som omger centrala politiska begrepp för att etablera de egna, snäva och monistiska definitionerna som allenarådande. Denna förenklande "avpluralisering" är förstås inte endast en funktion av radikala ideologier utan av alla ideologier. Syftet är också att göra det möjligt att känna igen vad som egentligen utmärker den egna ideologin i jämförelse med konkurrerande ideologier som "strider om legitima betydelser av politiska begrepp och de stärkande arrangemang som de formerar" (Freeden 1994, s. I40). Freedens ideologibegrepp framställer således ett dynamiskt och flexibelt system, vilket inte med nödvändighet behöver uppvisa en hög grad av koherens (enligt Freeden är det snarare möjligt att analysera olika ideologiska inriktningar inom sociala rörelser som nära besläktade med varandra, som löst relaterade till varandra eller som blandformer), en ideologisk enighet bland rörelsens anhängare eller en samstämmighet mellan rörelsens ideologi och anhängarnas handlingar.

Det är endast när vi förstår radikala sociala rörelser som tävlingsinriktade aktörer i en hård konkurrens mellan olika ideologier - som antingen försöker etablera nya politiska idéer eller återinföra gamla - där det icke- 
radikala samhället (till exempel den liberala demokratin) utgör den konkurrerande aktören, som vi kommer att kunna begripa att radikala sociala rörelser i sitt väsen representerar en (radikal eller extrem) ideologi som är oupplösligt förbunden med den rådande ideologin i sin kamp för ideologisk överlevnad. Den "radikala" naturen bakom en radikal social rörelses specifika ideologi kan här definieras som inneboende oförenlighet med den ideologi som är rådande i målsamhället. Ett exempel på detta är antagandet att våld som kvasifilosofisk, meningsskapande föreställning tillhör högerextrema rörelsers ideologiska kärna, vilken baseras på en grundläggande åtskillnad mellan värdigt och ovärdigt liv (liv som en ständig kamp för att bevisa den egna nationens eller rasens överlägsenhet). Som en konsekvens av detta tenderar högerextrema grupper att framställa demokratiska politiska strukturer som svaga eller dekadenta, inte minst eftersom dessa strukturer raserar den bärande mekanismen för upprätthållandet av rasistisk överlägsenhet - våld och våldsutövning (Hennig 1983). Detta innebär också att den högerextremistiska ideologins centrala politiska begrepp inte är fredliga och att de på längre sikt inte kan existera vid sidan om eller som del av ett pluralistiskt demokratiskt samhälle. Följaktligen tvingas båda sidor - den radikala rörelsen och det icke-radikala samhället - i sitt nödvändiga ställningstagande gentemot varandra till olika former av angrepp och försvar, vilka kan vara såväl våldsamma som fredliga. Med tanke på detta växelspel blir det också begripligt varför och hur dessa båda sidor reagerar på varandra som de gör (se t.ex. Bendt 20I4).

Denna kamp eller denna konkurrens mellan ideologier utgör grunden för begreppet "kontrastsamhälle" och är en central drivkraft bakom gruppspecifika och individuella radikaliseringsprocesser.

\section{Det radikala kontrastsamhället och individuell radikalisering}

Begreppet "kontrastsamhället" (från latinets contrastare: motstå, stå emot varandra'), som hänvisar till några radikala och extrema grupper, användes för första gången av kriminologen Bernd Wagner, en av grundarna till Exit Deutschland som är ett tyskt program för avhoppare från höger-

5. Men också contra stare: utöva motstånd. Red. anm. 
extrema rörelser. Begreppet utgör en central del av hans teori om kulturell subversion och han beskriver det högerextrema kontrastsamhället som "summan av beteenden och attityder som utgör vardagskulturen i olika samhällssektorer, sociala grupper, miljöer och institutioner och som är präglade av föreställningarna om människans ojämlikhet, djungelns lag, sociala relationers biologiskt-etniska determinering, samhället som en levande organism, nationalism, antiliberalism samt en allmänt antidemokratisk hållning” (Wagner 1998). Wagners teoretiska modell innehåller redan flera centrala element som beskrivits ovan men den har varken utarbetats till en mer sammanhängande och heltäckande teori eller integrerats $\mathrm{i}$ en bredare kontext av forskning kring individuell eller grupprelaterad radikalisering.

I föreliggande artikel menas med begreppet "radikalt kontrastsamhälle" interaktionsmekanismen mellan radikala sociala rörelser och deras omgivande samhälle inom ett givet socialt system (inklusive infrastrukturen och ideologin). Denna mekanism börjar med den radikala sociala rörelsen och har som mål att styra såväl det positiva som det negativa målsamhället i en ideologiskt önskvärd riktning för att slutligen åstadkomma en ideologiskt rensad version av samhället. Som en del av denna strävan skapas alternativa sociala miljöer och nischer i det positiva målsamhället. Kontrastsamhällen erbjuder sålunda en livsmiljö för ideologier som är oförenliga med sin omgivning.

Ett centralt kännetecken för radikala sociala rörelser är, vilket ovan beskrivits som rörelsens mål, att ideologiskt och praktiskt förändra målsamhället, vilket innebär att det negativa målsamhället raseras samtidigt som rörelsen tar kontroll över det positiva målsamhället. Högerextrema grupper vill avskaffa en demokratisk och pluralistisk regering för att åter basera nationen på den biologiska rasismens grundprinciper. Utöver detta måste det positiva målsamhället (till exempel den "ariska" befolkningen) accepteras eller förändras för att man ska kunna genomdriva en ideologiskt driven version av målsamhället. För att uppnå dessa mål använder radikala sociala rörelser såväl ideologi som infrastruktur. Infrastrukturen är nödvändig för att en radikal social rörelse fysiskt ska kunna interagera med sina målsamhällen. I negativa termer (kampen mot och utplåningen av den ideologiska fienden) avser infrastrukturen 


\section{Det radikala kontrastsambället}

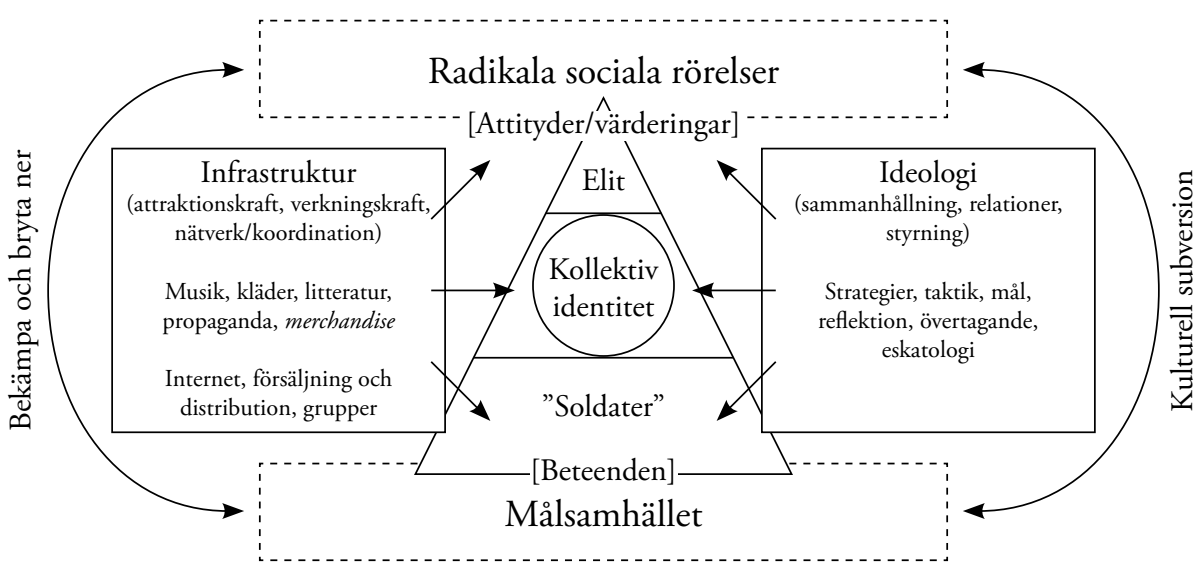

brottslig verksamhet, terroristgrupper eller enskilda våldsdåd, det vill säga varje fysisk aktivitet som har en destruktiv effekt och syftar till att förstöra det negativa målsamhället. I positiva termer är infrastrukturen nödvändig för att rekrytera nya medlemmar och för att sprida rörelsens ideologi med hjälp av musik, konserter, möten och manifestationer, tjänster, försäljning av varor, publikationer, webbsidor etc.

Ideologin erbjuder också ett urval av centrala politiska begrepp som är essentiella för den meningsskapande processen, problemdefinitionen samt urvalet av strategier och taktiker. Ideologin tillhandahåller vidare en rad grundläggande definitioner av dels rörelsens fiender och dels mer övergripande kategorier, till exempel hur rörelsens framtidsvision av det positiva målsamhället ska utformas.

Ideologin vidareförmedlas med hjälp av specifika åtgärder inom ramen för olika element av rörelsens infrastruktur, exempelvis evenemang eller ekonomisk verksamhet där fiendebilden kommer till uttryck i bland annat låttexter, slagord på klädesplagg, utrop under manifestationer eller efterlämnade symboler på brottsplatser. Således syftar den radikala sociala rörelsen genom själva utformningen av sin infrastruktur till att avlägsna, rubba, infiltrera eller förändra den ideologiska kärnan och 
periferin hos rörelsens positiva och negativa målsamhällen, för att det bättre ska stämma överens med den egna rörelsens ideologi. Det innebär konkret att den radikala rörelsens destruktiva potential realiseras och verkställs genom denna kombination av infrastruktur och ideologi.

En granskning av kontrastsamhället, både som en sammanhängande helhet och som uppbyggt av enskilda beståndsdelar såsom ideologi, infrastruktur, hierarki, radikal social rörelse och målsamhällen, och dess betydelse för individuella radikaliseringsmekanismer, visar tydligt på den centrala interaktionen mellan grupp och individ. I denna artikel finns flera exempel på att radikalisering inte enbart kan definieras som inskolningen in i radikala miljöer eller en speciell förkärlek för våld, utan att den måste förstås som en internaliseringsprocess av en specifik radikal ideologi som $\mathrm{i}$ sig är oförenlig med det omgivande samhällets dominanta ideologi. Internaliseringen avser således en komplex helhet av politiska idéer (värderingar, definitionen av vänner respektive fiender, problemdefinitioner och så vidare), som i sin tur utgör grunden för individuella handlingsramar.

Betydelsen av denna växelverkan mellan grupp och individ i radikaliseringsprocesser har hittills endast undersökts tämligen sporadiskt och ytligt. Resonemanget här baseras på en mer utförlig kvalitativ studie från 2014 vars resultat ger en inblick i före detta tyska högerextremisters individuella radikaliseringsprocesser (Köhler 20I4b). Ett dynamiskt kretslopp mellan individuella föreställningar och grupprelaterade aktiviteter beskrivs som ett viktigt led i den radikaliseringsmodell som utvecklas i den studien. I modellen konfronteras individuella, fortfarande ganska abstrakta och opolitiska, värderingar och föreställningar om självförverkligande och personliga uttryck med upplevelsen av hur den radikala gruppen iscensätter sin image inför omvärlden. Denna konfrontation kan ske på många olika sätt, till exempel på konserter, fester eller demonstrationer, genom litteratur, genom att "födas in i rörelsen", genom vänner och bekanta med mera. I samtliga fall som beskrivs i studien var inträdet i den högerextrema miljön resultatet av ett medvetet beslut (Köhler 20I4b, s. 338). När en person väl hade blivit medlem i en grupp (processen som krävs för att bli medlem måste studeras separat) fylldes dessa abstrakta värderingar med ett politiskt innehåll, det vill säga med ett konkret politiskt program och konkreta visioner om vilka politiska mål som ska upp- 
nås. Denna process skulle också kunna betecknas som "ideologisering" eftersom problemdefinitionen (till exempel orättvisor mot det egna folket) länkas ihop med konkreta metoder för att lösa problemet (till exempel demonstrationer, våld mot migranter) samt en specifik vision om politiska mål (till exempel ett Tyskland fritt från migranter). Denna sammanlänkning sker kognitivt och praktiskt genom integrationen i gruppens aktiviteter (dess infrastruktur), antingen mer passivt som deltagare eller mer aktivt som organisatör.

Radikala sociala rörelser strävar följaktligen efter att integrera sina medlemmar i rörelsens aktiviteter i enlighet med medlemmarnas talanger, kunskaper och intressen, för att befästa rörelsens kollektiva identitet och rörelsespecifika ideologi. Konkret finns en konformitet mellan radikaliseringsmekanismens strävan efter att monopolisera betydelsen av enskilda politiska idéer och begrepp (till exempel "rättvisa", "frihet", "ära", "makt") hos de enskilda medlemmarna och rörelseideologin, en konformitet som etableras och förstärks genom individens integration i rörelsens infrastruktur och hierarki.

Om enskilda medlemmar är fast övertygade om att demokratin till exempel innebär förstörelsen av "den tyska kulturen”, eller att individuell "frihet" är möjlig endast inom ramen av en "krigisk oberoende ras", föreligger en klassisk radikalisering (ideologisering) som är inbäddad i ett radikalt kontrastsamhälle. Genom att absorbera och integrera rörelsens ideologi och genom att integreras i rörelsens infrastruktur skapar och upprätthåller man dessutom en kollektiv identitet. Denna identitet kan definieras som en "större manifestation av gruppattribut och likheter mellan medlemmarna på en social nivå” (Adams \& Roscigno 2005, s. 759) vars funktion är "att bygga solidaritet och uthållighet bland rörelsens medlemmar genom en tro på rörelsens egna politiska eller sociala effektivitet, att konstruera kollektiva motiv för deltagande och att skapa nya definitioner av den sociala verkligheten och skildringar av den motsatta 'andre"' (Adams \& Roscigno 2005, s. 759; se även Gamson 1995; Meyer \& Staggenborg 1996; Kebede m.fl. 2000; Melucci 1995; Snow m.fl. I986; Taylor \& Whittier 1995).

Ännu mer tillspetsat kan sägas att kontrastsamhällets kamp mot en eller flera fientliga ideologier ligger till grund för en ömsesidig radikali- 
seringsprocess för både gruppen och individen, samtidigt som den också ger upphov till en "oppositionell kultur" vars huvudsakliga funktion är identitetsskapande och upprätthållande av solidaritet inom rörelsen, men också tillhandahållande av alternativa tolkningsramar för hanteringen av missförhållanden och en upplevelse av egenmakt, det vill säga att själv kunna uppnå förändringar och framgång (framför allt Adams \& Roscigno 2005; Gamson 1995; Snow 2001; Taylor \& Whittier 1995).

Sammanfattningsvis kan man således säga att det framför allt är växelverkan mellan en radikal social rörelses ideologi och infrastruktur som ger upphov till en dynamik av ömsesidig radikalisering (ideologisering) på basis av en tävling eller konkurrens med målsamhällenas ideologi. Så länge denna mekanism inte uppmärksammas i tillräcklig utsträckning när samhället ska bedöma radikala eller extremistiska miljöer är det svårt att genomföra meningsfulla och belysande analyser av radikala gruppers eller individers beteendemönster eller strategier. Tar man inte hänsyn till denna mekanism förvrängs dessutom såväl en användbar bedömning av riskerna med radikaliseringen som motsvarande samhälleliga åtgärder för prevention, intervention och repression.

\section{Översättning: Paul Fuehrer}

\section{Referenser}

Adams, Josh \& Roscigno, Vincent. J. 2005. "White Supremacists, Oppositional Culture and the World Wide Web", Social Forces, 84, 2, s. 759-778. DoI: http://dx.doi.org/IO.I353/sof.2006.000I

Backes, Uwe 20I2. "Rechtsterroristische Kristallisationsfelder in Europa. Formen und Transnationale Netze im Vergleich", Politische Studien. Orientierung durch Information und Dialog, volym 63.

Bendt, Jörg D. 20I4. "Ideological Immunity in the German Media Coverage of Domestic Terrorism", Journal Exit-Deutschland. Zeitschrift für Deradikalisierung und demokratische Kultur, nr I, s. 65-96.

URL: http://journals.sfu.ca/jed/index.php/jex/article/view/57 (7 februari 20I6)

Benford, Robert D. 1993. "Frame Disputes Within the Nuclear Disarmament Movement", Social Forces, 7I, 3, s. 677-70I. DoI: http://dx.doi.org/Io.Io93/sf/7I.3.677

Benford, Robert D. \& Hunt, Scott 1992. ”Dramaturgy and Social Movements. The Social Construction and Communication of Power", Sociological Inquiry, 62, I, s. 36-55. DoI: http://dx.doi.org/IO.IIII/j.I475-682X.1992.tbooI82.x 
Benford, Robert D. \& Snow, David A. 2000. "Framing Processes and Social Movements. An Overview and Assessment", Annual Review of Sociology, volym 26, s. 6II-639. DoI: http://dx.doi.org/Io.II46/annurev.soc.26.I.6II

Bittner, Egon 1963. "Radicalism: A Study of the Sociology of Knowledge", American Sociological Review, volym 28, s. 928-940.

Bjørgo, Tore 20II. "Dreams and Disillusionment: Engagement in and Disengagement from Militant Extremist Groups", Crime, Law and Social Change, 55, 4, s. 277-285. DoI: http://dx.doi.org/IO.IO07/sIo6II-OII-9282-9

Borah, Porismita 20II. "Conceptual Issues in Framing Theory: A Systematic Examination of a Decade's Literature", Journal of Communication, 61, 2, s. 246-263. DoI: http://dx.doi.org/IO.IIII/j.I460-2466.20II.0I539.x

Borstel, Dierk \& Heitmeyer, Wilhelm 20I2. "Menschenfeindliche Mentalitäten, radikalisierte Milieus und Rechtsterrorismus", i Malthaner, Stefan \& Waldmann, Peter (red.) Radikale Milieus. Das soziale Umfeld terroristischer Gruppen. Frankfurt am Main: Campus Verlag.

Brown, Timothy S. 2004. "Subcultures, Pop Music and Politics: Skinheads and 'Nazi Rock' in England and Germany", Journal of Social History, 38, I, s. 157-178. DoI: http://dx.doi.org/I0.1353/jsh.2004.0079

Chong, Dennis \& Druckman, James N. 2007. "Framing Theory", Annual Review of Political Science, volym Io, s. I03-126. DoI: http://dx.doi.org/IO.II46/annurev.polisci.IO.072805.103054

Clarke, John 1979. "Stil", i Honneth, Axel, Lindner, Rolf \& Paris, Rainer (red.) Jugendkultur als Widerstand. Milieus, Rituale, Provokationen. Frankfurt am Main: Syndikat.

Cotter, John M. 1999. "Sounds of Hate: White Power Rock and Roll and the Neo-nazi Skinhead Subculture", Terrorism and Political Violence, II, 2, s. III-I4O. DoI: http://dx.doi.org/I0.I080/09546559908427509

Dalgaard-Nielsen, Anja 2008. Studying Violent Radicalization in Europe I. The Potential Contribution of Social Movement Theory. DIIS Working Paper. Köpenhamn: DIIS. URL: http://www.econstor.eu/bitstream/I04I9/84630/I/DIIS2008-02.pdf (7 februari 2016)

della Porta, Donatella 1995. Social Movements, Political Violence, and the State. A Comparative Analysis of Italy and Germany. Cambridge: Cambridge University Press.

della Porta, Donatella 2008. "Research on Social Movements and Political Violence", Qualitative Sociology, 3I, 3, s. 22I-230.

DOI: http://dx.doi.org/I0.I007/sin133-008-9109-x

della Porta, Donatella 20I3. Clandestine Political Violence. New York: Cambridge University Press.

Diani, Mario I992. "The Concept of Social Movement", The Sociological Review, 40, I, S. I-25.

Dor: http://dx.doi.org/IO.IIII/j.I467-954X.1992.tbo2943.x

Ezekiel, Raphael S. 2002. "An Ethnographer Looks at Neo-Nazi and Klan Groups. The Racist Mind Revisited", American Behavioral Scientist, 46, I, s. 5I-7I. Dor: http://dx.doi.org/Io.II77/000276420204600I005 
Fitzgerald, Kathleen J. \& Rodgers, Diane M. 2000. "Radical Social Movement Organizations: A Theoretical Model", The Sociological Quarterly, 4I, 4, s. 573-592. DOI: http://dx.doi.org/IO.IIII/j.I533-8525.2000.tbooo74.x

Freeden, Michael 1994. "Political Concepts and Ideological Morphology", Journal of Political Philosophy, 2, 2, s. I40-164. DoI: http://dx.doi.org/Io.IIII/j.I467-9760.1994.tbooor9.x

Frindte, Wolfgang \& Neumann, Jörg 2002. "Wie ideologisiert sind rechtsextreme Gewalttäter?", i Bis hierher - und wie weiter? Pädagogische Konzepte zum professionellen Umgang mit Rechtsextremisten. Erfurt: Thüringer Justizministerium.

Frindte, Wolfgang, Neumann, Jörg \& Wiezorek, Christine 2003. ”Biographische Hintergründe und Motivationen fremdenfeindlicher Gewalttäter”, i Ahlheim, Klaus (red.) Intervenieren, nicht resignieren. Rechtsextremismus als Herausforderung für Bildung und Erziehung. Schwalbach am Taunus: Wochenschau, s. 49-64.

Frindte, Wolfgang, Neumann, J., Hieber, K., Knote, A. \& Müller, C. 20or. "Rechtsextremismus = 'Ideologie plus Gewalt'. Wie ideologisiert sind rechtsextreme Gewalttäter", Zeitschrift für Politische Psychologie, 9, 2-3, s. 8I-98.

Fromm, Rainer 1998. Die "Wehrsportgruppe Hoffmann". Darstellung, Analyse und Einordnung. Ein Beitrag zur Geschichte des deutschen und europäischen Rechtsextremismus. Frankfurt am Main: Lang.

Fuchs, Marek 2003. "Rechtsextremismus von Jugendlichen. Zur Erklärungskraft verschiedener theoretischer Konzepte", Kölner Zeitschrift für Soziologie und Sozialpsychologie, 55, 4, s. 654-678.

DOI: http://dx.doi.org/I0.I007/sII577-003-0I16-3

Futrell, Robert, Simi, Pete \& Gottschalk, Simon 2006. "Understanding Music in Movements: The White Power Music Scene", The Sociological Quarterly, 47, 2, s. 275-304. DOI: http://dx.doi.org/IO.IIII/j.I533-8525.2006.00046.x

Gamson, William A. I988. "Political Discourse and Collective Action", International Social Movement Research, I, 2, s. 219-244.

Gamson, William A. 1995. "Constructing Social Protest", i Johnston, Hank \& Klandermans, Bert (red.) Social Movements and Culture, vol. 4. Minneapolis: University of Minnesota Press, s. 85-106.

Garner, Roberta Ash \& Zald, Mayer N. 1985. ”The Political Economy of Social Movement Sectors", i Suttles, Gerald D., Zald, Mayer N. \& Janowitz, Morris (red.) The Challenge of Social Control. Citizenship and Institution Building in Modern Society. Essays in Honor of Morris Janowitz. Norwood: Ablex Pub.

Heitmeyer, Wilhelm (red.) 1992. Die Bielefelder Rechtsextremismus-Studie. Erste Langzeituntersuchung zur politischen Sozialisation männlicher Jugendlicher. Weinheim och München: Juventa-Verlag.

Hennig, Eike 1983. "Wert habe ich nur als Kämpfer. Rechtsextremistische Militanz und neonazistischer Terror", i Steinweg, Reiner (red.) Faszination der Gewalt. Politische Strategie und Alltagserfahrung. Frankfurt am Main: Suhrkamp.

Hinrichs, Günter 2003. "Persönlichleitsprofile und Schulkarrieren rechter Gewalttäter", i Kaufmann, Kerstin (red.) Ein Bündnis zwischen Bildung und Justiz gegen Rechts- 


\section{KÖHLER | HÖGEREXTREM TERRORISM SOM GRUPPFENOMEN?}

extremismus, Rassismus und Fremdenfeindlichkeit. Dokumentation der Potsdamer Fachkonferenz, Dienstag, 09.09. bis Freitag, I2.09. 2003 im Tagungshaus BlauArt in Potsdam. Norderstedt: Books on Demand.

Hoffman, Bruce 1986. Right-Wing Terrorism in West Germany. Santa Monica: RAND.

Hopf, Christel \& Schmidt, Christiane (red.) 1993. Zum Verhältnis von innerfamilialen sozialen Erfahrungen, Persönlichkeitsentwicklung und politischen Orientierungen. Dokumentation und Erörterung des methodischen Vorgehens in einer Studie zu diesem Thema. Universität Hildesheim, Institut für Sozialwissenschaften.

Hundeide, Karsten 2003. "Becoming a Committed Insider", Culture \& Psychology, 9, 2, s. I07-I27. DoI: http://dx.doi.org/I0.II77/1354067X039200I

Jaschke, Hans Gerd 2006. Politischer Extremismus. Wiesbaden: VS Verlag für Sozialwissenschaften.

Jesse, Eckhard 20I2. "Rechtsterroristische Strukturen in Deutschland. Vergangenheit und Gegenwart", Politische Studien. Orientierung durch Information und Dialog, volym 63, s. 24-35.

Kalinowsky, Harry H. 1985. Rechtsextremismus und Strafrechtspflege. Eine Analyse von Strafverfahren wegen mutmasslicher rechtsextremistischer Aktivitäten und Erscheinungen. Bonn: Bundesministerium der Justiz.

Kebede, Alem Seghed, Shriver, Thomas E. \& Knottnerus, J. David 200o. "Social Movement Endurance: Collective Identity and the Rastafari", Sociological Inquiry, 70, 3, s. $313-337$.

DoI: http://dx.doi.org/IO.IIII/j.I475-682X.200o.tboo9II.x

Klönne, Arno 1989. "Aufstand der Modernisierungsopfer", Blätter für deutsche und internationale Politik, 34, 5, s. 545-548.

Koopmans, Ruud \& Rucht, Dieter 1996. "Rechtsradikalismus als soziale Bewegung?” i Falter, Jürgen W., Jaschke, Hans-Gerd \& Winkler, Jürgen R. (red.) Rechtsextremismus. Ergebnisse und Perspektiven der Forschung. Sonderheft 27 der Politischen Vierteljahresschrift. Opladen: Westdeutscher Verlag, s. 265-287.

Köhler, Daniel 20I4a. "The German 'National Socialist Underground (NSU)' and Anglo-American Networks. The internationalization of Far-Right Terror", i Jackson, Paul \& Shekhovtsov, Anton (red.) The Postwar Anglo-American Far Right. A Special Relationship of Hate. Basingstoke: Palgrave.

Köhler, Daniel 20r4b. "Right-wing Extremist Radicalization Processes: The Formers' Perspective", Journal Exit-Deutschland. Zeitschrift für Deradikalisierung und demokratische Kultur, nr I, s. 307-377.

URL: http://journals.sfu.ca/jed/index.php/jex/article/view/64 (7 februari 20I6)

Macklin, Graham 20I3. "'Onward Blackshirts!' Music and the British Union of Fascists", Patterns of Prejudice, 47, 4-5, s. 430-457.

Dor: http://dx.doi.org/I0.1080/0031322X.2013.845447

McAdam, Doug, Tarrow, Sidney \& Tilly, Charles 2003. "Dynamics of Contention", Social Movement Studies, 2, I, s. 99-102.

DOI: http://dx.doi.org/IO.IO80/I4742837.2003.I0035370 
McCarthy, John D. \& Zald, Mayer N. 1973. The Trend of Social Movements in America. Professionalization and Resource Mobilization. Morristown: General Learning Press.

McCarthy, John D. \& Zald, Mayer N. 1977. "Resource Mobilization and Social Movements: A Partial Theory", The American Journal of Sociology, 82, 6, s. I2I2-I24I. URL: http://www.jstor.org/stable/2777934

McVeigh, Rory, Myers, Daniel J. \& Sikkink, David 2004. "Corn, Klansmen, and Coolidge: Structure and Framing in Social Movements", Social Forces, 83, 2, s. 653-690. DoI: http://dx.doi.org/I0.1353/sof.2005.00I9

Melucci, Alberto 1992. Nomader i nuet. Sociala rörelser och individuella behov i dagens samhälle. Göteborg: Daidalos.

Melucci, Alberto 1995. "The Process of Collective Identity", i Johnston, Hank \& Klandermans, Bert (red.) Social Movements and Culture, vol. 4. Minneapolis: University of Minnesota Press, s. 4I-63.

Mentzel, Thomas 1998. Rechtsextremistische Gewalttaten von Jugendlichen und Heranwachsenden in den neuen Bundesländern. Eine empirische Untersuchung von Erscheinungsformen und Ursachen am Beispiel des Bundeslandes Sachsen-Anhalt. München: Fink.

Meyer, David S. \& Staggenborg, Suzanne 1996. "Movements, Countermovements, and the Structure of Political Opportunity", American Journal of Sociology, IOI, 6, s. 1628I660.

URL: http://www.jstor.org/stable/2782II4

Mudde, Cas 200o. The Ideology of the Extreme Right. Manchester: Manchester University Press.

Möller, Kurt 2005. "Männliche Sozialisation und Gewalt", i Pech, Detlef, Herschelmann, Michael \& Fleßner, Heike (red.) Jungenarbeit. Dialog zwischen Praxis und Wissenschaft. Dokumentation der Tagung vom I8. November 2004 an der Carl von Ossietzky-Universität Oldenburg. Oldenburg: BIS.

Möller, Kurt \& Schuhmacher, Nils 2007. Rechte Glatzen. Rechtsextreme Orientierungsund Szenezusammenhänge: Einstiegs. Verbleibs- und Ausstiegsprozesse von Skinheads. Wiesbaden: Springer Verlag.

Neubacher, Frank 1998. Fremdenfeindliche Brandanschläge. Eine kriminologisch-empirische Untersuchung von Tätern, Tathintergründen und gerichtlicher Verarbeitung in Jugendstrafverfahren. Godesberg: Forum-Verlag.

Neumann, Jörg \& Frindte, Wolfgang 2002. "Gewaltstraftaten gegen Fremde. Eine situativ-motivationale Analyse", Journal für Konflikt-und Gewaltforschung, 4, 2, s. 95-III. URL: http://www.uni-bielefeld.de/ikg/jkg/2-2002/neumann_frindte.pdf (7 februari 20I6)

Oliver, Pamela \& Johnston, Hank 200o. "What a Good Idea! Ideologies and Frames in Social Movement Research", Mobilization: An International Quarterly, 5, I, s. 37-54. URL: http://mobilizationjournal.org/doi/abs/I0.I78I3/maiq.5.I.g54k22208634625I (7 februari 20I6)

Pfahl-Traughber, Armin 2003. "Rechtsextremismus als neue soziale Bewegung? Aktivitäten und Kooperation von NPD, Neonazis und Skinheads", Forschungsjournal Neue Soziale Bewegungen, I6, 4, s. 43-54. 
Pfahl-Traughber, Armin 20I2a. "Der Rechtsterrorismus im Verborgenen: Darstellung und Einschätzung der Besonderheiten des 'Nationalsozialistischen Untergrundes", Jahrbuch Terrorismus, volym 5, 20II-20I2, s. 93-I2O.

URL: http://budrich-journals.de/index.php/terrorismus/article/view/II529 (7 februari 20I6)

Pfahl-Traughber, Armin 20I2b. "Geschichte des Rechtsterrorismus in der Bundesrepublik Deutschland. Eine Analyse zu Entwicklung, Gruppen und Vergleich", Einsichten und Perspektiven. Bayrische Zeitschrift für Politik und Geschichte, nr I, s. I6-3I.

Rabert, Bernhard 1995. Links- und Rechtsterrorismus in der Bundesrepublik Deutschland von 1970 bis heute. Bonn: Bernard \& Graefe.

Rippl, Susanne 2002. "Bildung und Fremdenfeindlichkeit. Die Rolle schulischer und familialer Sozialisation zur Erklärung von Bildungsunterschieden im Ausmaß von fremdenfeindlichen Einstellungen”, Kölner Zeitschrift für Soziologie und Sozialpsychologie, 54, I, s. 135-I46.

DoI: http://dx.doi.org/I0.I007/sII577-002-0006-0

Rippl, Susanne \& Seipel, Christian 2002. ”Ökonomische Lage, Bildungsniveau und Fremdenfeindlichkeit. Die Bedeutung von Autoritarismus und Anomie: ein theorie-integrierendes Modell”, i Boehnke, Klaus, Hagan, John \& Fuß, Daniel (red.) Jugendgewalt und Rechtsextremismus. Soziologische und psychologische Analysen in internationaler Perspektive. Weinheim och München: Juventa-Verlag.

Rippl, Susanne, Boehnke, Klaus, Hefler, Gerd \& Hagan, John 1998. "Sind Männer eher rechtsextrem und wenn ja, warum? Individualistische Werthaltungen und rechtsextreme Einstellungen", Politische Vierteljahresschrift, 39, 4, s. 758-774.

Roszak, Theodore 1969. The Making of a Counter Culture. Reflections on the Technocratic Society and its Youthful Opposition. Garden City: Anchor.

Sageman, Marc 2008. Leaderless Jihad. Terror Networks in the Twenty-first Century. Philadelphia: University of Pennsylvania Press.

Shaffer, Ryan 2013. "The Soundtrack of Neo-fascism: Youth and Music in the National Front", Patterns of Prejudice, 47, 4-5, s. 458-482.

Dor: http://dx.doi.org/10.I080/0031322X.2013.842289

Snow, David A. 200I. "Collective Identity and Expressive Forms", i Smelser, Neil \& Baltes, Paul D. (red.) International Encyclopedia of the Social and Behavioral Sciences. Oxford: Pergamon Press, s. 2212-2219.

Snow, David A. 2004. "Framing Processes, Ideology, and Discursive Fields." i Snow, David A., Soule, Sarah Anne \& Kriesi, Hanspeter (red.) The Blackwell Companion to Social Movements. Malden: Blackwell.

Snow, David. A. \& Benford, Robert D. 1988. ”Ideology, Frame Resonance, and Participant Mobilization", International Social Movement Research, I, I, s. 197-217.

Snow, David A. \& Benford, Robert D. 1992. "Master Frames and Cycles of Protest", i Morris, Aldon D. \& McClurg Mueller, Carol (red.) Frontiers in Social Movement Theory. New Haven: Yale University Press.

Snow, David A., Rochford, E. B., Worden, S. K. \& Benford, R. D. 1986. "Frame Alignment Processes, Micromobilization, and Movement Participation", American Socio- 
logical Review, 5I, 4, s. 464-48I.

URL: http://www.jstor.org/stable/209558I

Steinberg, Marc W. 1998. "Tilting the Frame: Considerations on Collective Action Framing from a Discursive Turn", Theory and Society, 27, 6, s. 845-872.

DoI: http://dx.doi.org/Io.IO23/A:I006975321345

Taylor, Verta \& Whittier, Nancy 1995. "Analytical Approaches to Social Movement Culture: The Culture of the Women's Movement", i Johnston, Hank \& Klandermans, Bert (red.) Social Movements and Culture, vol. 4. Minneapolis: University of Minnesota Press.

Tilly, Charles 1978. From Mobilization to Revolution. New York: McGraw-Hill.

Tilly, Charles 1984. "Social Movements and National Politics", i Bright, Charles \& Harding, Susan (red.) Statemaking and Social Movements. Essays in History and Theory. Ann Arbor: University of Michigan Press.

Touraine, Alain 1977. The Self-Production of Society. Chicago: University of Chicago Press.

Touraine, Alain 1981. The Voice and the Eye. An Analysis of Social Movements. Cambridge: Cambridge University Press.

Touraine, Alain 1985. "An Introduction to the Study of Social Movements", Social Research, 52, 4, s. 749-787.

URL: http://www.jstor.org/stable/40970397

Turner, Ralph H. \& Killian, Lewis M. 1987. Collective Behavior. 3 uppl. Don Mills: Pearson Education.

Ueltzhöffer, Jörg 1993. "Wir sollten in Zukunft von Menschenfeindlichkeit reden”, Frankfurter Rundschau, I6 mars I993, s. IO.

Virchow, Fabian 2004. "The Groupuscularization of Neo-Nazism in Germany: The Case of the Aktionsbüro Norddeutschland", Patterns of Prejudice, 38, I, s. 56-70.

Dor: http://dx.doi.org/I0.I080/0031322032000185587

Wagner, Bernd 1998. "Im Osten nichts neues", Bulletin. Schriftenreihe des Zentrum Demokratische Kultur, nr 2.

Wahl, Klaus 200I. Fremdenfeindlichkeit, Antisemitismus, Rechtsextremismus. Drei Studien zu Tatverdächtigen und Tätern, vol. 3. Bonn: Bundesministerium des Innern.

Wahl, Klaus (red.) 2003. Skinheads, Neonazis, Mitläufer. Täterstudien und Prävention, vol. 5. Wiesbaden: VS Verlag für Sozialwissenschaften.

Wendt, Frank, Lau, Steffen \& Kröber, Hans Ludwig 2002. ”Rechtsradikale Gewalttäter", Rechtsmedizin, I2, 4, s. 214-223.

DoI: http://dx.doi.org/IO.I007/sooI94-002-0I54-6

Wiktorowicz, Quintan (red.) 2004a. Islamic Activism. A Social Movement Theory Approach. Bloomington: Indiana University Press.

Wiktorowicz, Quintan 2004b. Joining the Cause. Al-Muhajiroun and Radical Islam, paper framlagt på konferensen The Roots of Islamic Radicalism på Yaleuniversitetet 8-9 maj 2004.

Wiktorowicz, Quintan 2006. "Anatomy of the Salafi Movement", Studies in Conflict \& Terrorism, 29, 3, s. 207-239.

DOI: http://dx.doi.org/Io.I080/I0576100500497004 
Willems, Helmut 1993. "Gewalt gegen Fremde. Täter, Strukturen und Eskalationsprozesse", Der Bürger im Staat, 43, 2, s. I43-I48.

Willems, Helmut, Eckert, Roland, Würtz, Stefanie \& Steinmetz, Linda 1993. Fremdenfeindliche Gewalt. Einstellungen, Täter, Konflikteskalation. Opladen: Leske und Budrich.

Willems, Helmut, Würtz, Stefanie \& Eckert, Roland 1994. Analyse fremdenfeindlicher Straftäter. Forschungsprojekt. Bonn: Bundesminister des Innern.

Yinger, J. Milton 1960. "Contraculture and Subculture", American Sociological Review, 25,5 , s. $625-635$.

URL: http://www.jstor.org/stable/2090136

Yinger, J. Milton 1982. Countercultures. The Promise and the Peril of a World Turned Upside Down. New York: Free Press.

Zeskind, Leonard 2009. Blood and Politics. The History of the White Nationalist Movement from the Margins to the Mainstream. New York: Farrar, Straus \& Giroux.

Zick, Andreas \& Küpper, Beate 2009. "Rechtsextremismus Erscheinungsformen, Strategien und Ursachen", i Beelman, Andreas \& Jonas, Kai J. (red.) Diskriminierung und Toleranz. Wiesbaden: VS Verlag für Sozialwissenschaften. 


\section{Moderna klassiker}

\section{Norbert Elias}

John L. Scotson

\section{Etablerade och outsiders}

\section{Arkiv förlag}

Norbert Elias (1897-I990) var en av I900-talets mest betydande sociologer. I Etablerade och outsiders (nu tillgänglig i en andra utvidgad upplaga) visar han på ett fascinerande sätt hur moralisk stigmatisering är en allmänt förekommande maktteknik varhelst det finns en konflikt mellan en etablerad och dominerande grupp och en underordnad, dominerad grupp; mellan bofasta och invandrare, vita och svarta i USA, högkastiga och kastlösa indier, män och kvinnor, välbeställda och fattiga.

Översättning Anita Sandberg \& Gunnar Sandin Arkiv förlag, 296 sidor 